\title{
Natural woodlands hold more diverse, abundant, and unique biota than novel anthropogenic forests: a multi-group assessment
}

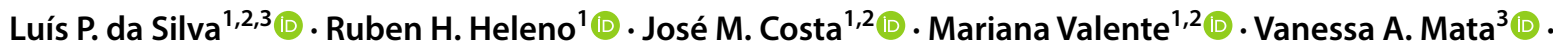

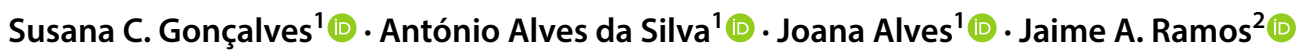

Received: 15 September 2018 / Revised: 9 January 2019 / Accepted: 22 February 2019

(c) Springer-Verlag GmbH Germany, part of Springer Nature 2019

\begin{abstract}
Biodiversity sustained by natural ecosystems, particularly forests, provides ecosystem services essential to human wellbeing. However, many forests have been severely transformed, notably via monospecific plantations and the spread of invasive species. Given the extension of these novel anthropogenic forests (plantations and invasive copses), it is critical to know how they can support forest biodiversity, particularly in highly humanized biodiversity hotspots as the southwest Mediterranean Europe. Because the effects likely vary across taxonomic groups, such assessments require an integrative multi-group approach. Here, we evaluated the abundance, richness, and composition of shrubs, herbs, macrofungi, ground and flying arthropods, birds, small mammals, carnivores, and bats across the four most common forest types in Central Portugal, namely: natural oak woodlands (dominated by Quercus faginea Lam.) and anthropogenic forests, invasive Acacia dealbata Link copses, Pinus pinaster Aiton plantations (native), and Eucalyptus globulus Labill. plantations (exotic). Oak woodlands sustained higher abundance, diversity, and a unique species composition compared to the other forests, especially those dominated by exotic species. The greatest changes in biodiversity occurred in herbs and birds. Contrary to our expectations, species richness and composition of macrofungi and carnivores in acacia copses were similar to those of oak woodlands, revealing that groups respond differently to forest changes. The large-scale replacement of natural forests by novel anthropogenic forests has significant negative impacts in most, but not all groups, which should be actively considered for integrative conservation strategies.
\end{abstract}

Keywords Biodiversity loss $\cdot$ Monospecific forests $\cdot$ Novel ecosystems $\cdot$ Tree plantations

Communicated by Lluís Coll.

Electronic supplementary material The online version of this article (https://doi.org/10.1007/s10342-019-01183-5) contains supplementary material, which is available to authorized users.

Luís P. da Silva

1fpascoals@gmail.com

1 CFE - Centre for Functional Ecology - Science for People and the Planet, Department of Life Sciences, University of Coimbra, Calçada Martim de Freitas, 3000-456 Coimbra, Portugal

2 MARE - Marine and Environmental Sciences Centre, Department of Life Sciences, University of Coimbra, 3000-456 Coimbra, Portugal

3 CIBIO-InBIO, Research Centre in Biodiversity and Genetic Resources, University of Porto, 4485-661 Vairão, Portugal

\section{Introduction}

Biodiversity has a crucial role in supporting ecosystem functioning and resilience (Mace et al. 2012). However, humans gained the capacity to severely alter their surroundings, shaping natural landscapes and their biodiversity (Foley 2005). Most terrestrial taxa are found in forests (Lindenmayer et al. 2006 and references therein), which deliver a wide range of supporting, provisioning, regulating, and cultural ecosystem services (Thompson et al. 2011; Mace et al. 2012; Haines-Young and Potschin 2017). For this reason, forests are one of the most valuable ecosystems globally both in ecological and economic terms (Costanza et al. 1997). However, provisioning services tend to be more valued due to their direct market price than supporting or regulating services (Costanza et al. 1997; Bremer and Farley 2010). Raw material production has been optimized by plantation forests (sensu Carle and 
Holmgren 2003) mainly of monospecific stands, often of exotic species due to their fast growing rates (Carnus et al. 2006; Paquette and Messier 2010). Similarly, invasive species are frequently fast growing species that benefit from disturbance such as fires, and often are able to form monoculture copses (Royo and Carson 2006; Thompson et al. 2011). Worldwide, the area of natural forests (sensu Carle and Holmgren 2003) is decreasing, while the area occupied by novel forests (i.e. composed of invasive exotic tree species) and exotic plantations is expanding (Payn et al. 2015; FAO 2016). Given the human modification of forests (Foley 2005), it is critical to understand the possible consequences of this large-scale land-use change from natural to novel forests (sensu Hobbs et al. 2006) on biodiversity.

Natural forests in Europe have been altered for millennia (Kaplan et al. 2009), first with a dominance of forest clearing for agriculture and then, in the last century, with an increase in plantation forests (Forest Europe 2015; Payn et al. 2015; FAO 2016). One third of Europe is covered by forests, but around $80 \%$ of them are actively managed for the supply of raw materials (Forest Europe 2015). The Mediterranean basin, one of the world's biodiversity hotspots (Myers et al. 2000) that supports many threatened and endemic species (Malcolm et al. 2006), is under high anthropogenic pressure (Cuttelod et al. 2008). Given the present extension of novel forests in the Mediterranean region and worldwide, their effect in the conservation of biodiversity cannot be ignored (Carnus et al. 2006). Several studies suggest that in Southwest Europe, monospecific plantations and forests dominated by exotic species sustain lower biodiversity than original natural forests, but these studies are mostly restricted to single taxonomic groups, typically plants and birds (e.g. Calviño-Cancela 2013; Calviño-Cancela et al. 2012; Proença et al. 2010; Tellería and Galarza 1990). However, different organisms are likely to respond distinctively to land-use changes: for example, while birds tend to be less diverse in exotic forests, several arthropods might not be affected or even benefit from this disturbance (Barlow et al. 2007; Irwin et al. 2014). Therefore, a multi-taxa approach is necessary to fully understand the impact of novel forests on biodiversity.

Here, we evaluated the compositional biodiversity of vascular plants (shrubs and herbs), macrofungi, ground and flying arthropods, birds, small mammals, carnivores, and bats in four common forest types in south-western Europe, namely: unmanaged natural oak woodlands, Pinus pinaster Aiton plantations (native species), Eucalyptus globulus Labill. plantations (exotic species), and unmanaged copses of Acacia dealbata Link (exotic invasive species). We expect to find a higher biodiversity in natural forests followed by the native plantations and a lower diversity in the planted and invasive exotic woodlands. We predict that intra-taxon trends observed at higher trophic levels would also be reflected at lower levels due to cascading effects.

\section{Materials and methods}

\section{Study area}

The study was performed near Coimbra, Central Portugal (Fig. 1), a region with Mediterranean climate. The mean annual temperature is $16^{\circ} \mathrm{C}$, and the mean annual precipitation is $886 \mathrm{~mm}$ (data from the Portuguese Institute for Sea and Atmosphere collected from 1981 to 2010). The landscape has a strong anthropogenic presence being very fragmented and covered mainly with urban (12\%), agricultural (32\%), and forest areas (55\%). Areas of subsistence agriculture (mainly cereals, vineyards and olive groves) have been abandoned in the last four decades, allowing the natural recovery of woodlands or sometimes the expansion of acacia trees (mainly Acacia dealbata), originally planted on the roadsides to prevent erosion and ornamental reasons. Natural woodlands are usually dominated by oaks (mainly Quercus faginea Lam.) and other typical Mediterranean vegetation (e.g. Arbutus unedo L., Olea europaea L., Pistacia lentiscus L., Q. suber L., Rhamnus alaternus L.), and have been unmanaged since land abandonment. In the study area, most of the forested area is increasingly occupied by novel plantations of the exotic Eucalyptus globulus (Calviño-Cancela et al. 2012; ICNF 2013). Eucalyptus plantations represent $26 \%$ of the country's forested area and since the 80 s have mainly replaced previous plantations of native Pinus pinaster that nevertheless still occupy $23 \%$ of the Portuguese forest (ICNF 2013). In the study area, pine plantations were also replaced by eucalyptus plantations or were progressively replaced by natural woodlands or invasive copses, after the outbreak of the pine wood nematode Bursaphelenchus xylophilus by the end of the twentieth century (Burgermeister et al. 1999; Valadas et al. 2012). Both plantation types are managed, with most trees planted after ploughing and with occasional understory removal. Pine plantations are usually logged every 30 to 40 years and then re-planted, while eucalyptus plantations are usually logged three times during this period and only then re-planted. Acacia dealbata is likely the most aggressive exotic tree species in Portugal, and its occupancy area has been rapidly increasing (Correia et al. 2014). It forms dense monospecific stands, especially after wildfires, due to a numerous and longlived seed banks with fire-induced germination and a fast growth rate (Lorenzo et al. 2010, 2012).

We selected 40 forest plots with structural mature trees, 10 of each type, randomly distributed in the study area (Fig. 1). Natural woodlands and pine plantations were at least 30 years old, while eucalyptus plantations and acacia copses were approximately half of that age. The selected plots had a continuous area of $100 \times 100 \mathrm{~m}$ of 


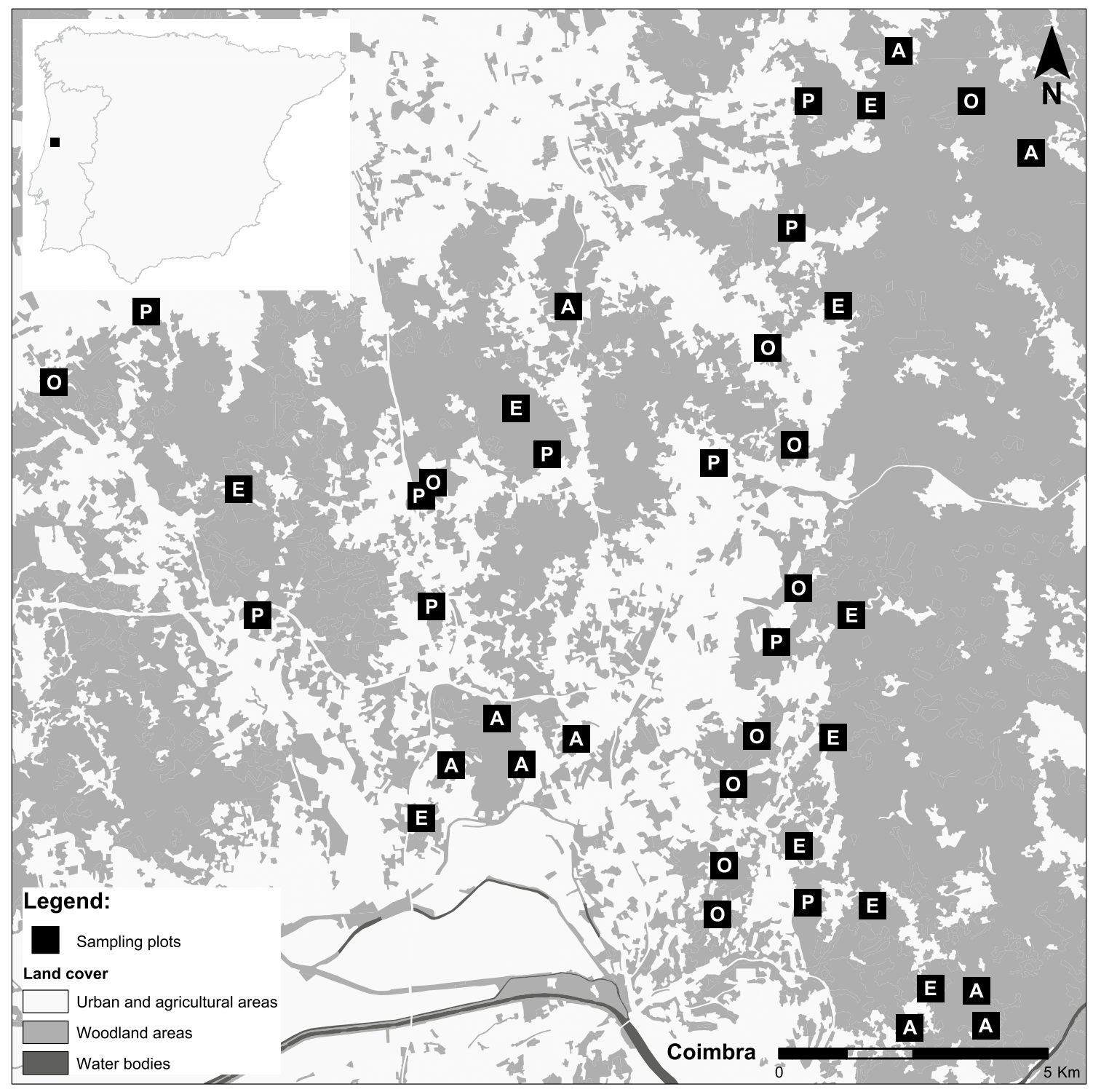

Fig. 1 Study area in Central Portugal. $\mathrm{O}$-oak woodlands, $\mathrm{P}$-pine plantations, $\mathrm{E}$ - eucalyptus plantations, and A—acacia copses

the same forest type, and similar forest-type plots were at least $1 \mathrm{~km}$ apart. Sampling was made in the centre of the plots to avoid edge effects. Biodiversity assessments were conducted between June 2013 and May 2014 (see below), except for two A. dealbata plots that were only sampled from June 2013 to December 2013, when they were logged.

\section{Sampling design}

\section{Plants}

Vascular plants were sampled in two different groups: shrubs and herbaceous plants (hereafter herbs). All plants were sampled from June to August 2013. Shrubs were counted and identified in five squares of $10 \times 10 \mathrm{~m}$, one in the centre of the plot and the other four at the centre of each quadrant (supplementary material, Fig. S1). The relative abundance of each shrub species was evaluated using percentage of shrub cover inside the $10 \times 10 \mathrm{~m}$ squares, visually estimated in $10 \%$ intervals. Herbs were sampled in 20 squares of $1 \times 1 \mathrm{~m}$ per plot, located along the four edges of each of the five $10 \times 10 \mathrm{~m}$ squares (supplementary material, Fig. S1) and its relative abundance was estimated by the ground area occupied (1\% intervals). We identified $87 \%$ of the plants to the species level, $12 \%$ to the genus level and the remaining to an upper level. When the species was not identified, plants were then separated into morphospecies (e.g. Carex sp. 1 and Carex sp.2). We followed the Portuguese Botanical Society (2014) plant nomenclature. 


\section{Macrofungi}

This group was sampled by running three $20 \times 2 \mathrm{~m}$ linear transects crossing at the centre of each plot (supplementary material, Fig. S1), in November and December of 2013. The abundance of macrofungi was estimated by counting all spore-fruiting bodies (i.e. mushrooms). When we were unable to identify the macrofungi species, these were classified into morphospecies of the lowest possible rank. Fungi nomenclature followed Buczacki et al. (2013).

\section{Arthropods}

Sampling of arthropods was divided in two groups: ground and flying arthropods. Ground arthropods were sampled in each plot with five pitfall traps placed in the centre of the $10 \times 10 \mathrm{~m}$ squares used in the vegetation sampling (supplementary material, Fig. S1). These were sampled in three seasons, from July to August 2013 (summer), January to February (winter), and April to May 2014 (spring). Pitfalls were operated during seven consecutive days (performing a total of 4060 trap days), had $7 \mathrm{~cm}$ of diameter, and were filled with ethylene glycol. Flying arthropods were sampled at night, captured with UV light funnel traps during one night per plot in April and May 2014 (38 trap nights). The light trap was placed in the centre of each plot, and it is likely to attract insects within a 30-m radius (Merckx and Slade 2014). Arthropod nomenclature followed Fauna Europaea (de Jong et al. 2014). When arthropods could not be identified to the species level, they were classified into the lower taxonomic group possible (usually Family) and then sorted into morphospecies.

\section{Vertebrates}

Vertebrates were sampled with specific methodologies for each of the four groups: birds, small mammals, carnivores, and bats. Birds, small mammals, and carnivores were sampled in three seasons, from July to August 2013 (summer), January to February 2014 (winter), and April to May 2014 (spring), while bats were only sampled in summer and spring when their activity is higher. Birds were sampled in two point counts (da Silva et al. 2012) per season, in the centre of each plot (supplementary material, Fig. S1). Point counts lasted $10 \mathrm{~min}$ and were performed during the first $2.5 \mathrm{~h}$ after sunrise, in days without strong winds or rain, and all birds seen or heard within a radius of $30 \mathrm{~m}$ were counted. Small mammals were captured using 21 Sherman traps in each plot, baited with oatmeal and sardines (Teixeira et al. 2017), during three consecutive nights, in all sampling seasons. The Sherman traps were placed along the previously described transects, $10 \mathrm{~m}$ apart (the central point had three traps; supplementary material, Fig. S1). All small mammals captured were marked with harmless cuts in the fur for individual recognition (Teixeira et al. 2017). Medium-sized carnivores (order carnivora) were sampled with camera traps (Bushnell Trophy Cam HD max) operated for four consecutive nights per season in the centre of each plot (supplementary material, Fig. S1). The relative abundance of carnivores was determined as the number of photographs taken of each species with a minimum of 1-h interval (Cruz et al. 2015). Bat sounds were recorded with a real-time bat detector (Echo Meter EM3 from Wildlife Acoustics), in a 10-min duration point recording in the centre of each plot, twice per season. The recording period occurred between $30 \mathrm{~min}$ and $2.5 \mathrm{~h}$ after nightfall, in nights without rain, strong winds or moonlight. Bat activity was quantified based on the number of bat passes recorded (Cruz et al. 2016) and used as a proxy of bat relative abundance. Bat identification was based on their ultra-sound pulses using Audacity 2.1.2 software (http:// audacity.sourceforge.net), using keys for Portuguese bats; only species known to occur in the study area were considered (Rainho et al. 2013). The exception was Miniopterus schreibersii, whose occurrences were excluded because its pulses are very similar to the much more abundant and overspread Pipistrellus pygmaeus (all possible M. schreibersii were classified as P. pygameus), and Plecotus sp. were only identified to genus. Vertebrate's nomenclature followed the Portuguese vertebrate red list (Cabral et al. 2005).

\section{Woodland characterization}

To rule out potential confounding landscape variables, plots were characterized in terms of the nearest distance to a water source, urban area, agricultural field and other non-forest land-use types, and plot elevation (from the plot centre). We also measured the area and perimeter of the entire woodland patch, i.e. the entire area of the patch with the same dominant tree species, measured in Google Earth Pro using orthophotos from June 2013. In addition to the percentage of shrub and herb cover, we also estimated the ground area occupied by deadwood and decaying leaves (1\% intervals) in the $201 \times 1 \mathrm{~m}$ squares (supplementary material, Fig. S1).

\section{Data analysis}

Woodland characterization variables were compared among the different forests with generalized linear models (GLM), or with generalized linear mixed models (GLMM) using plot as random factor (when there was more than one sample per plot) to control for pseudoreplication within the same plot. To compare the relative abundance of the several sampled groups among the different forest types, we also used generalized linear models (GLM) or, when necessary, generalized linear mixed models (GLMM). These included sampling season and 
the interaction between forest type and season as co-variables, and plot as random factor (when there was more than one sample per season or plot), assuming a Gaussian error distribution to increase the fit of the residuals. A similar procedure was used to compare species richness of the different groups, but using a Poisson error distribution in the models, due to its better fit to the residuals' distribution. Pairwise multiple comparisons among forest types were performed using Post-hoc Tukey's HSD test with Bonferroni correction. We also computed species accumulation curves using 1000 Mao Tau randomizations of the data obtained on each plot (Colwell et al. 2012) to assess differences in the total number of observed species across forest types. We considered that the estimated number of species (for a given group) differed between forests if the $95 \%$ confidence intervals of both woodland types did not overlap. In order to compare the species composition of each group among the four forests, seasons, and their interaction, we used a permutational multivariate analysis of variance (PERMANOVA with 1000 permutations) based on Bray-Curtis dissimilarity matrices. When there was more than one sample per plot/ season, we summed the number of individuals found per species for the analysis. Whenever a species group differed among forest types or season, we performed multiple comparisons with Bonferroni corrections to test which woodland types differed significantly from the rest. A Non-metric Multidimensional Scaling ordination (NMDS) was used to represent species composition across forest types. All statistical analysis were performed with packages MASS (Venables and Ripley 2002), lme4 (Bates et al. 2015), multcomp (Hothorn et al. 2008), and vegan (Oksanen et al. 2016) in $R$ ( $R$ Core Team 2016) with the exception of accumulation curves that were calculated in EstimateS (Colwell 2013). A significance level of $\alpha<0.05$ was considered for all statistical tests involving $p$-values.

\section{Results}

\section{Species abundance, richness, diversity, and composition}

Overall, 816 species/morphospecies were detected across all forests (Table 1). Oak woodlands were in general the most diverse forest type and acacia copses the less (Table 1; Fig. 2). Oak woodlands also had more unique species (i.e. those not found in any other forest type; Table 2). Species composition differed across all forest types (Table 3; supplementary material, Table S1). The most similar forest to natural oak woodlands in terms of species composition were pine plantations (Fig. 3; Table 2).

\section{Plants}

Acacia copses had a lower shrub abundance than both pine and eucalyptus plantations, while pine plantations had a higher herb abundance than the two exotic forests (Fig. 2). Acacia copses had on average less shrub and herb species, while oak woodlands had more (Fig. 2). Considering the total species richness in each forest type, there were no differences in the number of shrub species, but there were differences in the number of herb species (Fig. 2). The shrub and herb compositions differed among all forest types, except between the two plantation forests for shrubs, and between eucalyptus plantations and acacia copses for herbs (Table 3; supplementary material, Table S1). Oak woodlands had more unique species than the remaining forest types for the two vegetation strata (Table 2).

\section{Macrofungi}

Macrofungi were almost twofold more abundant and diverse in oak woodlands and acacia copses than in the eucalyptus and pine plantations (Fig. 2). Macrofungi
Table 1 Number of species/ morphospecies of each group identified on each forest type

\begin{tabular}{lrrrrr}
\hline & Oak woodlands & Pine plantations & $\begin{array}{l}\text { Eucalyptus } \\
\text { plantations }\end{array}$ & Acacia copses & Total \\
\hline Shrubs & 52 & 53 & 40 & 43 & 79 \\
Herbs & 91 & 62 & 52 & 14 & 140 \\
Macrofungi & 81 & 29 & 32 & 58 & 141 \\
Ground arthropods & 158 & 147 & 161 & 133 & 264 \\
Flying arthropods & 66 & 37 & 28 & 21 & 126 \\
Birds & 31 & 27 & 19 & 18 & 38 \\
Small mammals & 4 & 3 & 5 & 4 & 5 \\
Carnivores & 6 & 3 & 3 & 5 & 6 \\
Bats & 15 & 15 & 352 & 12 & 17 \\
Total & 504 & 379 & & 306 & 816 \\
\hline
\end{tabular}




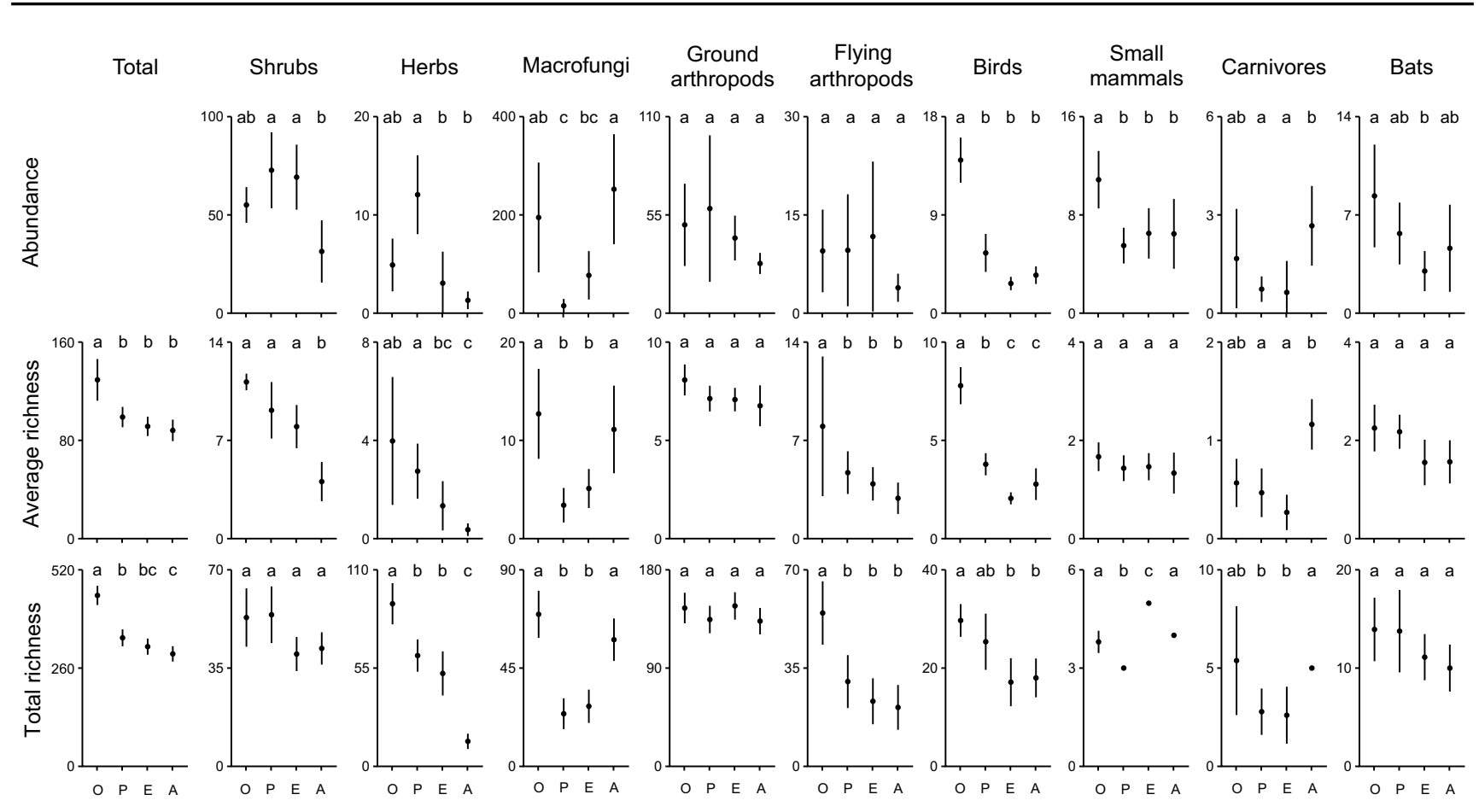

Fig. 2 Relative abundance, species richness, and total richness (Mao Tau accumulation curves) across forest types. Error bars represent the 95\% confidence intervals around the mean. Different letters on top of each forest type denote significant differences found between habitats (with GLMM for the relative abundance and species richness, and with 95\% confidence interval overlap for the total richness). O-oak woodlands, $\mathrm{P}$ - pine plantations, $\mathrm{E}$ - eucalyptus plantations, and $\mathrm{A}$ acacia copses
Table 2 Percentage of unique species (or morphospecies) in each woodland type and percentage of species (or morphospecies) shared between oak woodlands and the other forest types

\begin{tabular}{|c|c|c|c|c|c|c|c|}
\hline \multicolumn{5}{|l|}{$\%$ of unique species } & \multicolumn{3}{|c|}{$\begin{array}{l}\% \text { of species shared with oak } \\
\text { woodlands }\end{array}$} \\
\hline & Oak & Pine & Eucalyptus & Acacia & Pine & Eucalyptus & Acacia \\
\hline Global & 24 & 11 & 11 & 9 & 48 & 41 & 40 \\
\hline Shrubs & 15 & 9 & 5 & 8 & 73 & 49 & 49 \\
\hline Herbs & 29 & 15 & 14 & 1 & 38 & 29 & 12 \\
\hline Macrofungi & 33 & 8 & 6 & 23 & 17 & 20 & 26 \\
\hline Ground arthropods & 12 & 9 & 14 & 8 & 67 & 64 & 63 \\
\hline Flying arthropods & 43 & 18 & 14 & 10 & 11 & 5 & 11 \\
\hline Birds & 21 & 11 & 3 & 0 & 68 & 52 & 58 \\
\hline Small mammals & 0 & 0 & 20 & 0 & 75 & 100 & 100 \\
\hline Carnivores & 17 & 0 & 0 & 0 & 50 & 50 & 83 \\
\hline Bats & 6 & 6 & 0 & 0 & 87 & 73 & 67 \\
\hline
\end{tabular}

species composition differed across forests (Table 3) with oak woodlands and acacia copses having the highest number of shared species and the highest number of unique species (Table 2). Multiple comparisons of the species composition only detected differences between acacia copses and the two plantations, and between oak woodlands and pine plantations (supplementary material, Table S1).

\section{Arthropods}

Overall, ground and flying arthropod's abundance did not differ among forest types (Table 3; Fig. 2). However, the abundance of ground arthropods differed between seasons (Table 3; flying arthropods were only sampled in one season), being higher in summer. There was also a significant interaction between forest type and sampling season (Table 3): the abundance of ground arthropods in summer 
Table 3 Summary statistics of the GLM(M)s and PERMANOVAs used to compare forest types and (when applicable) sampling season and their interaction

\begin{tabular}{|c|c|c|c|c|c|c|c|c|c|}
\hline \multirow[b]{2}{*}{ Abundance } & \multicolumn{3}{|l|}{ Forest type } & \multicolumn{3}{|c|}{ Sampling season } & \multicolumn{3}{|l|}{ Interaction } \\
\hline & $\overline{\chi^{2}}$ & d.f. & $\overline{p \text { value }}$ & $\overline{\chi^{2}}$ & d.f. & $\overline{p \text { value }}$ & $\overline{\chi^{2}}$ & d.f. & $p$ value \\
\hline Shrubs & 14.878 & 3 & 0.002 & - & - & - & - & - & - \\
\hline Herbs & 25.862 & 3 & $<0.001$ & - & - & - & - & - & - \\
\hline Macrofungi & 18.401 & 3 & $<0.001$ & - & - & - & - & - & - \\
\hline Ground arthropods & 3.499 & 3 & 0.321 & 27.212 & 2 & $<0.001$ & 13.373 & 6 & $\mathbf{0 . 0 3 7}$ \\
\hline Flying arthropods & 1.530 & 3 & 0.676 & - & - & - & - & - & - \\
\hline Birds & 135.314 & 3 & $<0.001$ & 8.862 & 2 & 0.032 & 11.501 & 6 & 0.074 \\
\hline Small mammals & 21.833 & 3 & $<0.001$ & 25.038 & 2 & $<0.001$ & 6.507 & 6 & 0.369 \\
\hline Carnivores & 14.311 & 3 & 0.003 & 7.672 & 2 & 0.022 & 3.134 & 6 & 0.792 \\
\hline Bats & 8.070 & 3 & 0.045 & 1.093 & 1 & 0.298 & 6.537 & 3 & 0.088 \\
\hline Species richness & $\chi^{2}$ & d.f. & $p$ value & $\chi^{2}$ & d.f. & $p$ value & $\chi^{2}$ & d.f. & $p$ value \\
\hline Global & 113.870 & 3 & $<0.001$ & - & - & - & - & - & - \\
\hline Shrubs & 39.857 & 3 & $<0.001$ & - & - & - & - & - & - \\
\hline Herbs & 30.478 & 3 & $<0.001$ & - & - & - & - & - & - \\
\hline Macrofungi & 78.984 & 3 & $<0.001$ & - & - & - & - & - & - \\
\hline Ground arthropods & 8.677 & 3 & 0.034 & 284.913 & 2 & $<0.001$ & 17.020 & 6 & 0.009 \\
\hline Flying arthropods & 26.543 & 3 & $<0.001$ & - & - & - & - & - & - \\
\hline Birds & 162.015 & 3 & $<0.001$ & 5.710 & 2 & 0.058 & 15.306 & 6 & 0.018 \\
\hline Small mammals & 0.883 & 3 & 0.830 & 0.015 & 2 & 0.993 & 0.436 & 6 & 0.998 \\
\hline Carnivores & 18.272 & 3 & $<0.001$ & 10.926 & 2 & 0.004 & 1.928 & 6 & 0.926 \\
\hline Bats & 6.205 & 3 & 0.102 & 0.231 & 1 & 0.631 & 3.984 & 3 & 0.263 \\
\hline Species composition & Pseudo F & $R^{2}$ & $p$ value & Pseudo F & $R^{2}$ & $p$ value & Pseudo F & $R^{2}$ & $p$ value \\
\hline Global & 3.848 & 0.253 & $<0.001$ & - & - & - & - & - & - \\
\hline Shrubs & 5.020 & 0.294 & $<0.001$ & - & - & - & - & - & - \\
\hline Herbs & 2.979 & 0.199 & $<0.001$ & - & - & - & - & - & - \\
\hline Macrofungi & 1.985 & 0.145 & $<0.001$ & - & - & - & - & - & - \\
\hline Ground arthropods & 1.261 & 0.01 & 0.075 & 21.853 & 0.276 & $<0.001$ & 1.107 & 0.042 & 0.249 \\
\hline Flying arthropods & 1.511 & 0.118 & 0.015 & - & - & - & - & - & - \\
\hline Birds & 11.992 & 0.229 & $<0.001$ & 4.395 & 0.056 & $<0.001$ & 1.371 & 0.052 & 0.061 \\
\hline Small mammals & 4.135 & 0.093 & $<0.001$ & 6.357 & 0.095 & $<0.001$ & 0.797 & 0.0357 & 0.690 \\
\hline Carnivores & 3.911 & 0.093 & 0.005 & 2.394 & 0.038 & $<0.001$ & 0.860 & 0.041 & 0.652 \\
\hline Bats & 2.200 & 0.082 & 0.002 & 1.429 & 0.018 & 0.177 & 0.735 & 0.028 & 0.812 \\
\hline
\end{tabular}

Significant values are highlighted in bold

was higher in pine plantations than in acacia copses. Even though the diversity of ground arthropods was slightly affected by forest type (Table 3), this effect was lost when correcting $\alpha$ for the multiple comparisons (Fig. 2). Sampling season also influenced the species richness of ground arthropods (Table 3 ), being higher in summer than in winter. The interaction between forest type and season was significant, but not detected in subsequent multiple comparisons tests between forest types and seasons. Ground arthropod community structure was also only affected by sampling season, and not by forest type or its interaction with season (Table 3). Finally, flying arthropods were more diverse in oak woodlands than in the other forest types (Fig. 2), but their community composition differed only between oak woodlands and eucalyptus plantations (supplementary material, Table S1).

\section{Vertebrates}

The abundance of birds and small mammals was highest in oak woodlands (Fig. 2). The abundance of carnivores, however, was higher in acacia copses than in eucalyptus and pine plantations (Fig. 2). Finally, bats were more abundant in oak woodlands than in eucalypts plantations (Fig. 2). Sampling season affected the abundance of all vertebrate groups except bats (only sampled in spring and summer), but there 


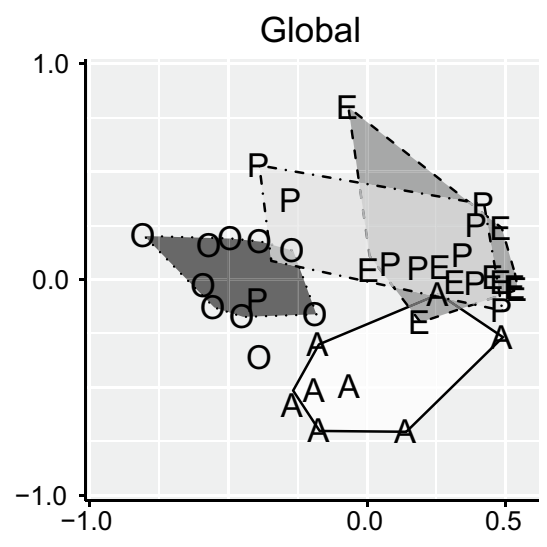

Shrubs

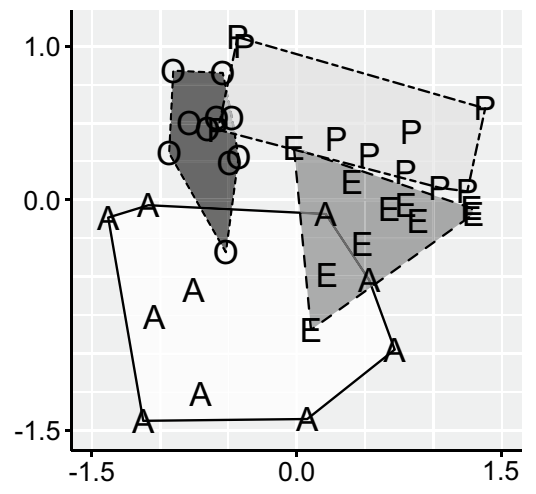

Ground arthropods

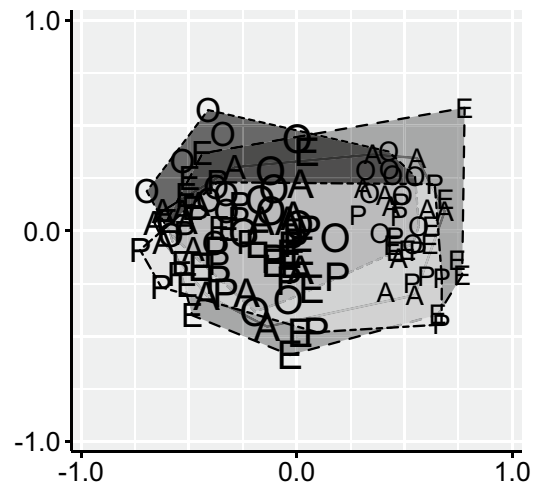

Small mammals

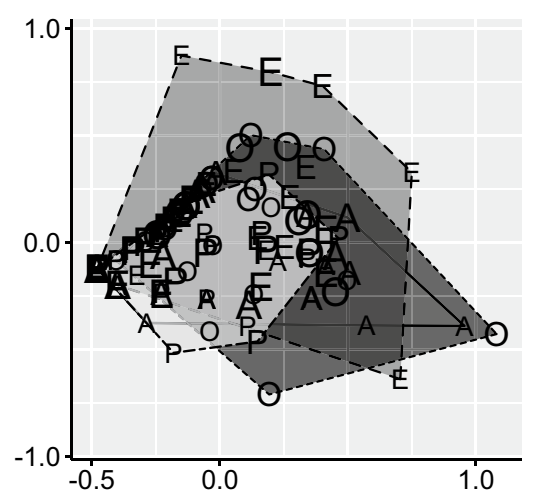

Herbs

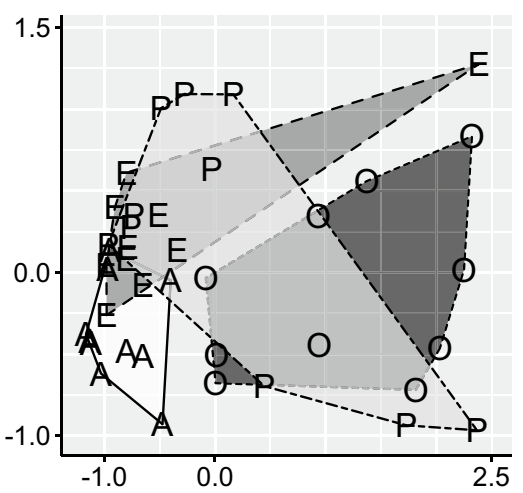

Flying arthropods

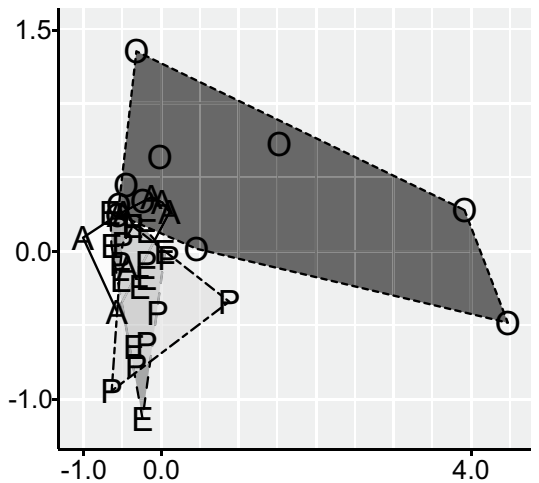

Carnivores

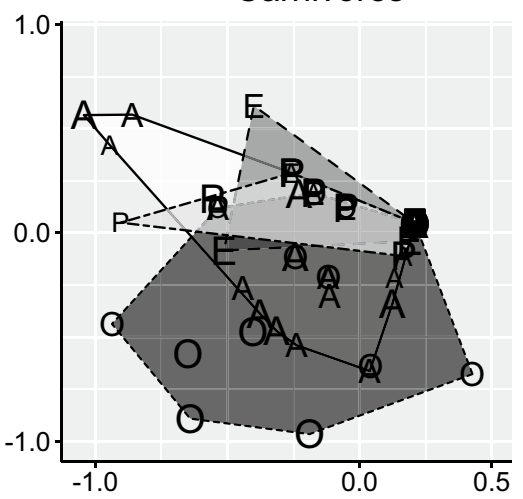

Macrofungi

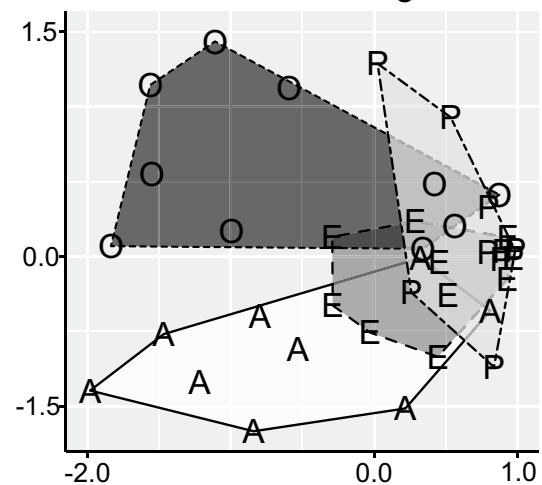

Birds

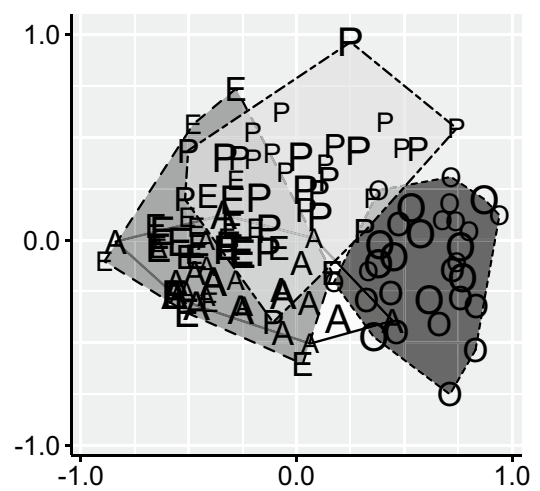

Bats

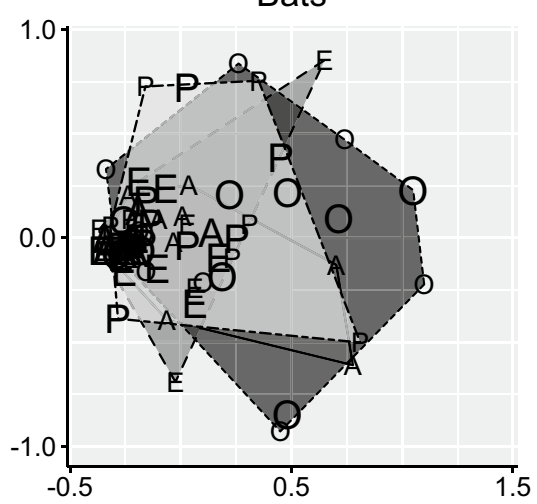


4Fig. 3 Non-metric Multidimensional Scaling ordinations (NMDS) representing the differences on species composition across the different forest types. Letters represent individual plots of each forest type (O-oak woodland; P-pine plantations; E-eucalyptus plantations; A-acacia copses) that are connected by the minimum convex polygon. Different letter sizes indicate the different sampling seasons, when the sample occurred in more than one season. Smaller font size represents summer sampling, intermediate font size represents winter sampling, and the larger font size represents spring sampling. The NMDS stress levels are, respectively (from top left to bottom right): 0.177 , $0.159,0.131,0.190,0.204,0.136,0.208,0.141,0.025$, and 0.200

was no seasonal effect on the abundance of any of the groups among forest types (Table 3). Bird abundance was greater in winter than in spring (summer was intermediate), small mammals were more abundant in winter and spring than in summer, and carnivores were more common in winter than in summer (intermediate in spring).

The number of vertebrate species was usually very low, except for birds (Table 1). Forest type and its interaction with season influenced bird richness, while season alone did not appear to be important (Table 3). In summer, birds were more diverse in oak woodlands, followed by pine plantations, and less diverse in exotic acacia and eucalyptus forests (Fig. 2). In winter, bird richness was highest in oak woodlands, while there were no differences among the other forest types. Oak woodlands were the most diverse forest type in spring, followed by pine plantations, acacia copses, and then eucalyptus plantations. Bird total richness also showed higher diversity in oak woodlands and less diversity in exotic (eucalyptus and acacia) forests (Fig. 2). Small mammals' average richness was not affected by forest type nor sampling season (Table 3). Carnivores' richness was greater in acacia copses than in pine and eucalyptus plantations (Fig. 2) and was lower in summer than in winter and spring (Table 3). Finally, bat richness was independent of season or forest type (Fig. 2; Table 3).

Both, forest type and season influenced vertebrate species composition, except for bats that were only influenced by forest type (Table 3). Bird community composition differed significantly among the four forest types (supplementary material, Table S1). Oak woodlands had more unique bird species, followed by pine plantations (Table 2). Pine plantations were the most similar to oak woodlands, while eucalyptus plantations were the more distinct (Fig. 3). Birds' composition was only similar between spring and summer. The differences in species composition for small mammals, carnivores, and bats were less conspicuous (Fig. 3). Small mammals' community composition differed only between two forest pairs: oak from acacia, and oak from pine forests (supplementary material, Table S1). The sampling season also affected small mammals' community composition (Table 3), except between winter and summer. Carnivores' composition differed between acacia copses and the two plantations, and also between winter and summer. Bats' community composition only differed between oak woodlands and eucalyptus plantations (supplementary material, Table S1).

\section{Woodland characterization}

Landscape variables were similar among all forests, except for forest patch area and perimeter $\left(\chi_{3}^{2}=14.619, p=0.002\right.$; $\chi_{3}^{2}=24.825, p<0.001$, respectively), which were higher in eucalyptus plantations (supplementary material, Fig. S2 a, b). Regarding the structural characteristics of each forest, shrub cover differed between woodlands $\left(\chi_{3}^{2}=34.234\right.$, $p<0.001$ ), being lowest in acacia copses and highest in oak woodlands (supplementary material, Fig. S2 c). Herbs covered greater area in pine plantations than on both exotic forests, while oak woodlands exhibited intermediate herb cover $\left(\chi_{3}^{2}=17.620, p=0.001\right.$; supplementary material, Fig. S2 d). Finally, acacia copses had a greater quantity of deadwood $\left(\chi_{3}^{2}=24.519, p<0.001\right)$ and decaying leaves $\left(\chi_{3}^{2}=18.876\right.$, $p<0.001)$ than the remaining forest types, although the quantity of decaying leaves did not differ from oak woodlands (supplementary material, Fig. S2 e, f).

\section{Discussion}

Here, we provided the first multi-group comparison of biodiversity across the most prevalent forest types of south-western Europe. Our results show that novel anthropogenic forests (plantations or invasive copses) sustain lower levels of biodiversity than natural oak forests, but that the effects are variable across forest types and groups of organisms. Multigroup biodiversity assessments of different forest types are extremely rare, with a few exceptions in Brazil (Barlow et al. 2007; Pardini et al. 2009), Canada (Aubin et al. 2013), USA (Sax 2002), UK (Quine and Humphrey 2010; Irwin et al. 2014), and New Zealand (Wood et al. 2017). In southwest Europe, previous studies recorded biodiversity declines from oak woodlands to pine and eucalyptus plantations, but these focused only at one or two taxa (Calviño-Cancela et al. 2012; Calviño-Cancela and Rubido-Bará 2013; Cruz et al. 2015, 2016; Teixeira et al. 2017), while biodiversity assessments in acacia copses are extremely scarce (Lorenzo et al. 2012).

As expected, we found an overall higher species abundance and diversity in natural oak woodlands than in monospecific forests. Of these monospecific forests, the native pine plantations were the most similar to oak woodlands. Environmental factors should have a minimum impact in our results given their similarity across all forest types. The only exception was the overall cover of eucalyptus plantations that occupied a larger area than the other woodlands in the region, due to the continuous increase in plantations for 
pulp production (Calviño-Cancela et al. 2012; ICNF 2013). Other unmeasured environmental variables (e.g. soil type, temperature) should also have no, or little, importance given the random selection of the sampled plots and the relatively restricted total area of sampling.

Lower tree strata diversity results agree with previous reports suggesting that eucalyptus plantations and acacia copses support lower levels of understory diversity than pine plantations and oak forests (Proença et al. 2010; Lorenzo et al. 2012; Calviño-Cancela et al. 2012). Nevertheless, our study shows for the first time that acacia copses are even poorer than eucalyptus plantations, especially regarding the herbaceous understory. Macrofungi are seldom evaluated in similar biodiversity studies and have never been evaluated in southern European forests. Therefore, until now we were largely unaware of how they might be affected by the spread of anthropogenic forest ecosystems. The macrofungi richness and abundance found is likely related to an almost lack of propitious microhabitats, such as dead wood and decaying leaves in the managed plantations (Paillet et al. 2010) and closed canopies (Twieg et al. 2007). It also reflects the lower tree diversity in monospecific stands, given the close intimacy between trees and ectomycorrhizal fungi (Nguyen et al. 2016). Regarding ground arthropods, previous studies found that Carabidae and Arachnida were more diverse and abundant in oak woodlands than in eucalyptus plantations (Martins da Silva et al. 2008; Zahn et al. 2009), collembola differed only in the number of species (Barrocas et al. 1998), and Isopoda are more abundant in eucalyptus plantations than in oak woodlands (Zahn et al. 2009). Our results could be a consequence of our analysis, where ground arthropods were all merged in the same analysis instead of being separated based on specific functional or taxonomic arthropod groups. In a different study, similar to ours, where ground arthropods were analysed as a whole, there were also no striking differences between natural forests and pine and eucalyptus plantations (Bara Temes et al. 1985). On the contrary, nocturnal flying arthropods exhibited differences in species diversity and composition among forests, likely related to the greater diversity of plants in natural oak woodlands, which provide a higher diversity of food for specialized species. This pattern is consistent with the results found for this group in other parts of the globe, e.g. Brazil (Bragança et al. 1998; Zanuncio et al. 1998).

Our results show that vertebrate diversity and abundance are generally higher in natural woodlands than in anthropogenic forests, confirming previous comparisons with both plantations types and extending them to the expanding acacia copses. Birds in particular show a remarkably consistent pattern across all studies (Tellería and Galarza 1990; Proença et al. 2010; da Silva et al. 2012; Calviño-Cancela 2013), likely responding to the higher plant diversity and cover of natural woodlands that offer a higher diversity of food sources and better shelter. Small mammal's diversity across forests types was similar to a previous assessment (Teixeira et al. 2017), as well as their abundance, which was negatively influenced by plantations (Gonçalves et al. 2012; Teixeira et al. 2017). Many southwest European carnivores seem to avoid eucalyptus plantations (Pereira et al. 2012; Cruz et al. 2015), but this did not occur in acacia copses. The relatively high occurrence of carnivores in acacia copses was the most surprising result of this study. This was likely driven by the lack of direct human disturbance, since there is (almost) no human visitation to acacia copses. This result may also help explaining why the abundance of small mammals in acacia copses, where there are plenty of large seeds available for rodents, is lower than in oak woodlands. Finally, the diversity of bat species was similar between oak woodlands and mature eucalyptus plantations, but a higher foraging activity was observed in oak woodlands, confirming the results found by Cruz et al. (2016). However, closed habitats are known to have lower bat's ultra-sound detectability (Bender et al. 2015), and given that oak woodlands have a higher vegetation cover than the other forest types, especially plantations, it is likely that the differences are more pronounced than the ones found.

\section{Conclusions}

Our results highlight the importance of broad multi-group studies in biodiversity assessments. Focusing on only a few indicator groups can often lead to misleading conclusions, as the impact of the forest types on biodiversity vary greatly across groups. We showed that the overall species abundance and richness in exotic woodlands, either plantations or copses of an invasive species, are lower than in natural forests, and native plantations frequently hold intermediate levels of species abundance and richness. The low biodiversity found in novel exotic forests seems to be associated with the habitat simplification of monospecific stands. Our results also highlight the importance of maintaining natural forests that are crucial biodiversity reservoirs, even in highly fragmented landscapes. While invasive species copses represent a threat both to biodiversity and to the economy, plantation forests are an important source of income. However, as novel forests continue to expand and natural forests patches are becoming increasingly rare, their capacity to sustain biodiversity needs to be actively considered during realistic and truly integrative conservation planning, and ecosystem services evaluation (Aragão et al. 2016).

Acknowledgements LPS, RHH, JMC, VAM, SGC, AAS, and JA were supported by the Portuguese Foundation for Science and Technology (FCT), through grants SFRH/BD/77746/2011, IF/00441/2013, SFRH/ BD/96292/2013, PD/BD/113462/2015, SFRH/BPD/101463/2014, SFRH/BD/75018/2010, and SFRH/BPD/123087/2016, respectively. 
LPS was also supported by the project POCI-01-0145-FEDER-030250, PTDC/ASP-SIL/30250/2017 - TOPDEVIL, co-financed by FCT and the European Regional Development Fund (FEDER) through Portugal 2020 Competitiveness and Internationalization Operational Programme (POCI).

Data availability Data is available online as supplementary material.

\section{References}

Aragão A, Jacobs S, Cliquet A (2016) What's law got to do with it? Why environmental justice is essential to ecosystem service valuation. Ecosyst Serv 22:221-227. https://doi.org/10.1016/j.ecose r.2016.09.012

Aubin I, Venier L, Pearce J, Moretti M (2013) Can a trait-based multitaxa approach improve our assessment of forest management impact on biodiversity? Biodivers Conserv 22:2957-2975. https ://doi.org/10.1007/s10531-013-0565-6

Bara Temes S, Rodriguez AR, del Carmen Gil Sotres M, Vazquez PM, Santos MA (1985) Efectos ecologicos del Eucalyptus globulus en Galacia: estudio comparativo con Pinus pinaster y Quercus robur. Instituto Nacional de Investigaciones Agrarias, Madrid

Barlow J, Gardner TA, Araujo IS et al (2007) Quantifying the biodiversity value of tropical primary, secondary, and plantation forests. Proc Natl Acad Sci U S A 104:18555-18560. https://doi. org/10.1073/pnas.0703333104

Barrocas HM, Gama MM, Sousa JP, Ferreira CS (1998) Impact of reafforestation with Eucalyptus globulus Labill. on the edaphic collembolan fauna of Serra de Monchique (Algarve, Portugal). Misc Zool 21:9-23

Bates D, Mächler M, Bolker B, Walker S (2015) Fitting linear mixedeffects models using lme4. J Stat Softw 67:1-48. https://doi. org/10.18637/jss.v067.i01

Bender MJ, Castleberry SB, Miller DA, Bently Wigley T (2015) Site occupancy of foraging bats on landscapes of managed pine forest. For Ecol Manag 336:1-10. https://doi.org/10.1016/j.forec o.2014.10.004

Bragança MAL, Zanuncio J, Picanço M, Laranjeiro AJ (1998) Effects of environmental heterogeneity on Lepidoptera and Hymenoptera populations in Eucalyptus plantations in Brazil. For Ecol Manag 103:287-292. https://doi.org/10.1016/S0378-1127(97)00226-0

Bremer LL, Farley KA (2010) Does plantation forestry restore biodiversity or create green deserts? A synthesis of the effects of land-use transitions on plant species richness. Biodivers Conserv 19:3893-3915. https://doi.org/10.1007/s10531-010-9936-4

Buczacki S, Shields C, Ovenden D (2013) Collins fungi guide: The most complete field guide to the mushrooms and toadstools of Britain and Ireland. HarperCollins, London

Burgermeister W, Sousa E, Mota M et al (1999) First report of Bursaphelenchus xylophilus in Portugal and in Europe. Nematology 1:727-734. https://doi.org/10.1163/156854199508757

Cabral MJ, Almeida J, Almeida PR et al (2005) Livro Vermelho dos Vertebrados de Portugal. Instituto da Conservação da Natureza, Lisbon

Calviño-Cancela M (2013) Effectiveness of eucalypt plantations as a surrogate habitat for birds. For Ecol Manag 310:692-699. https ://doi.org/10.1016/j.foreco.2013.09.014

Calviño-Cancela M, Rubido-Bará M (2013) Invasive potential of Eucalyptus globulus: seed dispersal, seedling recruitment and survival in habitats surrounding plantations. For Ecol Manag 305:129_ 137. https://doi.org/10.1016/j.foreco.2013.05.037

Calviño-Cancela M, Rubido-Bará M, van Etten EJB (2012) Do eucalypt plantations provide habitat for native forest biodiversity?
For Ecol Manag 270:153-162. https://doi.org/10.1016/j.forec o.2012.01.019

Carle J, Holmgren P (2003) Definitions related to planted forests. In: UNFF intersessional experts meeting on the role of planted forests in sustainable forest management. Wellington, New Zealand, pp 329-343

Carnus J, Parrotta J, Brockerhoff E et al (2006) Planted forests and biodiversity. J For 104:65-77. https://doi.org/10.1093/ jof/104.2.65

Colwell R (2013) EstimateS: statistical estimation of species richness and shared species from samples. Version 9. User's guide and application published at: http://purl.oclc.org/estimates. Accessed 01 Aug 2018

Colwell RK, Chao A, Gotelli NJ et al (2012) Models and estimators linking individual-based and sample-based rarefaction, extrapolation and comparison of assemblages. J Plant Ecol 5:3-21. https:// doi.org/10.1093/jpe/rtr044

Correia M, Castro S, Ferrero V et al (2014) Reproductive biology and success of invasive Australian acacias in Portugal. Bot J Linn Soc 174:574-588. https://doi.org/10.1111/boj.12155

Costanza R, Arge R, De Groot R et al (1997) The value of the world's ecosystem services and natural capital. Nature 387:253-260

Cruz J, Sarmento P, White PCL (2015) Influence of exotic forest plantations on occupancy and co-occurrence patterns in a mediterranean carnivore guild. J Mammal 96:854-865. https://doi. org/10.1093/jmammal/gyv109

Cruz J, Sarmento P, Rydevik G et al (2016) Bats like vintage: managing exotic eucalypt plantations for bat conservation in a Mediterranean landscape. Anim Conserv 19:53-64. https://doi.org/10.1111/ acv. 12216

Cuttelod A, García N, Malak DA et al (2008) The Mediterranean: a biodiversity hotspot under threat. In: Hilton-Taylor C, Stuart SN (eds) The 2008 review of the IUCN red list of threatened species. IUCN, Gland, pp 89-101

da Silva LP, Alves J, da Silva AA et al (2012) Variation in the abundance and reproductive characteristics of great tits Parus major in forest and monoculture plantations. Acta Ornithol 47:147-155. https://doi.org/10.3161/000164512X662250

de Jong Y, Verbeek M, Michelsen V et al (2014) Fauna Europaea-all European animal species on the web. Biodivers Data J 2:e4034. https://doi.org/10.3897/BDJ.2.e4034

FAO (2016) Global forest resources assessment 2015-how are the world's forests changing?. FAO, Rome

Foley JA (2005) Global consequences of land use. Science 309:570 574. https://doi.org/10.1126/science. 1111772

Forest Europe (2015) State of Europe's forests 2015. Forest Europe, Madrid

Gonçalves P, Alcobia S, Simões L, Santos-Reis M (2012) Effects of management options on mammal richness in a Mediterranean agro-silvo-pastoral system. Agrofor Syst 85:383-395. https://doi. org/10.1007/s10457-011-9439-7

Haines-Young R, Potschin M (2017) Common international classification of ecosystem services (CICES) V5.1 and guidance on the application of the revised structure

Hobbs RJ, Arico S, Aronson J et al (2006) Novel ecosystems: theoretical and management aspects of the new ecological world order. Glob Ecol Biogeogr 15:1-7. https://doi.org/10.1111/j.1466822X.2006.00212.x

Hothorn T, Bretz F, Westfall P (2008) Simultaneous inference in general parametric models. Biom J 50:346-363. https://doi. org/10.1002/bimj.200810425

ICNF (2013) Áreas dos usos do solo e das espécies florestais de Portugal continental. Instituto da Conservação da Natureza e das Florestas, Lisbon

Irwin S, Pedley SM, Coote L et al (2014) The value of plantation forests for plant, invertebrate and bird diversity and the potential 
for cross-taxon surrogacy. Biodivers Conserv 23:697-714. https ://doi.org/10.1007/s10531-014-0627-4

Kaplan JO, Krumhardt KM, Zimmermann N (2009) The prehistoric and preindustrial deforestation of Europe. Quat Sci Rev 28:30163034. https://doi.org/10.1016/j.quascirev.2009.09.028

Lindenmayer DB, Franklin JF, Fischer J (2006) General management principles and a checklist of strategies to guide forest biodiversity conservation. Biol Conserv 131:433-445. https://doi. org/10.1016/j.biocon.2006.02.019

Lorenzo P, González L, Reigosa MJ (2010) The genus Acacia as invader: the characteristic case of Acacia dealbata Link in Europe. Ann For Sci 67:101. https://doi.org/10.1051/forest/2009082

Lorenzo P, Pazos-Malvido E, Rubido-Bará M et al (2012) Invasion by the leguminous tree Acacia dealbata (Mimosaceae) reduces the native understorey plant species in different communities. Aust $\mathrm{J}$ Bot 60:669. https://doi.org/10.1071/BT12036

Mace GM, Norris K, Fitter AH (2012) Biodiversity and ecosystem services: a multilayered relationship. Trends Ecol Evol 27:19-25. https://doi.org/10.1016/j.tree.2011.08.006

Malcolm JR, Liu C, Neilson RP et al (2006) Global warming and extinctions of endemic species from biodiversity hotspots. Conserv Biol 20:538-548. https://doi.org/10.1111/j.1523-1739.2006.00364.x

Martins da Silva P, Aguiar CAS, Niemelä J et al (2008) Diversity patterns of ground-beetles (Coleoptera: Carabidae) along a gradient of land-use disturbance. Agric Ecosyst Environ 124:270-274. https://doi.org/10.1016/j.agee.2007.10.007

Merckx T, Slade EM (2014) Macro-moth families differ in their attraction to light: implications for light-trap monitoring programmes. Insect Conserv Divers 7:453-461. https://doi.org/10.1111/ icad. 12068

Myers N, Mittermeier RA, Mittermeier CG et al (2000) Biodiversity hotspots for conservation priorities. Nature 403:853-858. https:// doi.org/10.1038/35002501

Nguyen NH, Williams L, Vincent JB et al (2016) Ectomycorrhizal and saprotrophic fungal diversity are linked to different tree community attributes in a field-based tree experiment. Mol Ecol 25:4032-4046. https://doi.org/10.1111/mec.13719

Oksanen J, Blanchet FG, Friendly M et al (2016) Vegan: community ecology package. R package version 2.4. http://cran.r-project.org/ package=vegan. Accessed 01 Aug 2018

Paillet Y, Bergès L, Hjältén J et al (2010) Biodiversity differences between managed and unmanaged forests: meta-analysis of species richness in Europe. Conserv Biol 24:101-112. https://doi.org /10.1111/j.1523-1739.2009.01399.x

Paquette A, Messier C (2010) The role of plantations in managing the world's forests in the Anthropocene. Front Ecol Environ 8:27-34. https://doi.org/10.1890/080116

Pardini R, Faria D, Accacio GM et al (2009) The challenge of maintaining Atlantic forest biodiversity: a multi-taxa conservation assessment of specialist and generalist species in an agro-forestry mosaic in southern Bahia. Biol Conserv 142:1178-1190. https:// doi.org/10.1016/j.biocon.2009.02.010

Payn T, Carnus JM, Freer-Smith P et al (2015) Changes in planted forests and future global implications. For Ecol Manag 352:57-67. https://doi.org/10.1016/j.foreco.2015.06.021

Pereira P, Alves da Silva A, Alves J et al (2012) Coexistence of carnivores in a heterogeneous landscape: habitat selection and ecological niches. Ecol Res 27:745-753. https://doi.org/10.1007/s1128 4-012-0949-1

Portuguese Botanical Society (2014) Flora-on: Flora de Portugal Interactiva. www.flora-on.pt. Accessed 01 Aug 2018
Proença VM, Pereira HM, Guilherme J, Vicente L (2010) Plant and bird diversity in natural forests and in native and exotic plantations in NW Portugal. Acta Oecol 36:219-226. https://doi. org/10.1016/j.actao.2010.01.002

Quine CP, Humphrey JW (2010) Plantations of exotic tree species in Britain: irrelevant for biodiversity or novel habitat for native species? Biodivers Conserv 19:1503-1512. https://doi.org/10.1007/ s10531-009-9771-7

R Core Team (2016) R: a language and environment for statistical computing. R Foundation for Statistical Computing, Vienna, Austria. http://www.r-project.org/. Accessed 01 Aug 2018

Rainho A, Alves P, Amorim F, Marques JT (2013) Atlas dos morcegos de Portugal continental. Instituto de Conservação da Natureza e Florestas, Lisbon

Royo A, Carson W (2006) On the formation of dense understory layers in forests worldwide: consequences and implications for forest dynamics, biodiversity, and succession. Can J For Res 36:13451362. https://doi.org/10.1139/X06-025

Sax DF (2002) Equal diversty in disparate species assemblages: a comparison of native and exotic woodlands in California. Glob Ecol Biogeogr 11:49-57. https://doi.org/10.1046/j.1466822X.2001.00262.X

Teixeira D, Carrilho M, Mexia T et al (2017) Management of eucalyptus plantations influences small mammal density: evidence from Southern Europe. For Ecol Manag 385:25-34. https://doi. org/10.1016/j.foreco.2016.11.009

Tellería JL, Galarza A (1990) Avifauna and landscape in northern Spain: effects of reafforestations with exotic trees. Ardeola 37:229-245

Thompson ID, Okabe K, Tylianakis JM et al (2011) Forest biodiversity and the delivery of ecosystem goods and services: translating science into policy. Bioscience 61:972-981. https://doi.org/10.1525/ bio.2011.61.12.7

Twieg BD, Durall DM, Simard SW (2007) Ectomycorrhizal fungal succession in mixed temperate forests. New Phytol 176:437-447. https://doi.org/10.1111/j.1469-8137.2007.02173.x

Valadas V, Laranjo M, Barbosa P et al (2012) The pine wood nematode, Bursaphelenchus xylophilus, in Portugal: possible introductions and spread routes of a serious biological invasion revealed by molecular methods. Nematology 14:899-911. https://doi. org/10.1163/156854112X632673

Venables WN, Ripley BD (2002) Modern applied statistics with S, 4th edn. Springer, New York

Wood JR, Holdaway RJ, Orwin KH et al (2017) No single driver of biodiversity: divergent responses of multiple taxa across land use types. Ecosphere 8:e01997. https://doi.org/10.1002/ecs2.1997

Zahn A, Rainho A, Rodrigues L, Palmeirim JM (2009) Low macroarthropod abundance in exotic Eucalyptus plantations in the Mediterranean. Appl Ecol Environ Res 7:297-301

Zanuncio JC, Mezzomo JA, Guedes RNC, Oliveira AC (1998) Influence of strips of native vegetation on Lepidoptera associated with Eucalyptus cloeziana in Brazil. For Ecol Manag 108:85-90. https ://doi.org/10.1016/S0378-1127(98)00215-1

Publisher's Note Springer Nature remains neutral with regard to jurisdictional claims in published maps and institutional affiliations. 